\title{
REASONS FOR THE APPEAL FOR ANNULMENT ACCORDING TO THE NEW ROMANIAN CODE OF CIVIL PROCEDURE
}

\author{
A. Tabacu, R. Duminică
}

\begin{abstract}
Andreea Tabacu
Faculty of Law and Administrative Sciences

University of Pitesti, Pitesti, Romania

*Correspondence: Andreea Tabacu, 71 Bld. Republicii, Pitesti, Romania

E-mail: andreea.tabacu@upit.ro

\section{Ramona Duminică}

Faculty of Law and Administrative Sciences

University of Pitesti, Pitesti, Romania

*Correspondence: Ramona Duminica, 71 Bld. Republicii, Pitesti, Romania

E-mail: duminica.ramona@yahoo.com
\end{abstract}

\section{Abstract:}

With regards to the appeal for annulment, the New Romanian Code of Civil Procedure maintains the possibilities of exercising this extraordinary measure of contest, as regulated in the previous code. It adds, however, the reason for such a measure which is determined by not respecting the rules in assembling the judicial panel. These are essential rules of judicial activity and could have permanently affected the decisions of the appeal courts which could not be contested in any other way.

Keywords: reasons, appeal for annulment in common law, special appeal for annulment, New Romanian Code of Civil Procedure.

\section{Introduction}

Created in our legal system as a result of jurisprudence, the appeal for annulment was initially accepted in applying the former provisions of article 735 from the Romanian Code of Civil Procedure of 1865, which did not distinguish between the acts of procedure and judicial rulings ${ }^{l}$.

It was legally sanctioned by Law 18 from $1948^{2}$, keeping its specific features as an extraordinary remedy - used for retraction, impossible to suspend and open to all parts of the process which fit the hypothetical cases mentioned by the law - in all subsequent amended forms.

Currently, the New Romanian Code of Civil Procedure reestablishes the legal hypothesis for exercising this form of appeal, without suppressing any of the previous ones, on the contrary it adds the reason determined by the not respecting the rules for assembling the judicial panel.

\section{Appeal for annulment in common law}

\footnotetext{
${ }^{1}$ Article 735 from the Romanian Code of civil procedure from 1865 stipulated that the act of procedure was nullified if drawn up by an incompetent magistrate or court civil servant, i fit were drawn up in violation of the law, causing damages to the party which could not be mended any other way than by nullifying the document through law - I. Deleanu, Tratat de procedură civilă, vol. II, Noul Cod de procedură civilăa, "Universul Juridic" Publishing House, Bucharest, 2013, p. 310.

${ }^{2}$ I. Deleanu, Tratat de procedură civilă, vol. II, Noul Cod de procedură civilă, "Universul Juridic" Publishing House, Bucharest, 2013, p. 310.
} 
Article 503 paragraph 1 from the New Romanian Code of Civil Procedure stipulates that final decisions can be appealed by using this extraordinary appeal when the appellant was not duly summoned or was not present at the time of the judgement.

However, the annulment cannot be accepted when the actionable citation could have been rejected through appeal, given the sentences or decisions which can be appealed, pronounced with the stipulations pertaining to the citation. In such circumstances, the code requires that the compulsory reason be cited through an ordinary or extraordinary appeal, but which takes priority over the appeal for annulment.

If the appellate exercised the ordinary or extraordinary appeal and invoked the lack of citation, the appeal for annulment is not open to him/her, because the respective reason has already been analyzed, and the solution is given by the New Code of Civil Procedure. Thus, if he invoked this aspect via appeal or extraordinary appeal, but the appellate court presented with the appeal has assessed the legal provisions found in the citation, even if wrong, the appeal for annulment in common law can no longer be exercised to reiterate the hypothesis mismanaged citations.

It is of no interest whether the party exercised the ordinary appeal or the extraordinary appeal, but it is necessary to assess that these could have been exercised, because they were stipulated by the code despite the decision. The appellant is informed by the solution, since it was communicated to him/her.

Obviously, if the appellant was not aware of this legal solution, since the procedure of communication was not carried out, it is assumed that the appellant cannot exercise these because of the essential aspect of adversarial. In these cases the term is not renewed on these forms of appeal, because they have not commenced yet and the court will go on to resolve these appeals. As such, if the matter of appeal is raised or the appeal for annulment, faced with the inability to exercise these extraordinary appeal procedures as long as the appeal is still open, it will be settled and the appeal for annulment will be dismissed as inadmissible. Also, when the extraordinary appeal and the appeal for annulment have been exercised, the latter procedure takes priority in the conditions of simultaneous exercise of these extraordinary remedies.

If the extraordinary appeal was exercised and the reason for the lack of citation was invoked in the appeal request, the appeal may be accepted if the court of appeal rejected it because it needed to run checks that were incompatible with the extraordinary appeal or if the appeal through no fault of the party, was dismissed without being examined on its merits. Thus, if the court of appeal rejected it, given that it could not verify on the basis of the documents or new evidence submitted on appeal that the proper summoning procedure was not followed, it is necessary to be bring forth other evidence concerning the summons to inform the party of their duty to pick up the summons from the local authority (false registration) etc., the appeal for annulment may be brought against the decision of extraordinary appeal. If, however, the extraordinary appeal was rejected as being too late, something that is determined by fault of the party and involves that is not be researched on its merits, the appeal for annulment may not be approved because the party has exhausted the legal option to analyse the criticism of the summons on merits.

The rulings given in first and last instance are still subject to these forms of appeal, because in their case the law stipulates no ordinary or extraordinary appeal.

The appeal for annulment will not be able to be used against the decision to appeal, if it was exercised as a result of the agreement of the parties, for the purposes of directly appealing a ruling subject to appeal, because through such a convention the party that could have invoked the remedy of appeal has waived this possibility. The fact that under the law the parties involved in this appeal may invoke only aspects related to the violation or misapplication of rules of substantive law (article 459 from the New Romanian Code of Civil Procedure), does not open offer the party the possibility to appeal in annulment, because the act of disposition which must be done in the course of exercising this remedy. 
A ruling cannot be challenged through appeal for annulment more than once, although the reasons invoked in the second application are different and therefore from the moment the ruling is delivered, the party should identify the reasons for the appeal and invoke them.

The reason for the annulment in common law represents in reality a reason for nullification, violating the summoning procedure and the adversarial, the right to defense ${ }^{3}$ leading to the annulment of the ruling. If this possibility did not exist, the ruling would be delivered without meeting the compulsory requirements of the summons or writ, which ensures the adversarial quality of the civil suit, this despite the fact that the interested party did all everything to prevent such errors, citing the appeal based on these reasons ${ }^{4}$.

\section{Special appeal for annulment}

The special appeal for annulment regulated in the New Romanian Code of Civil Procedure is aimed at situations where the ruling of the court of appeal:

a) was delivered by a court without the authority or in violation of laws concerning the composition of the judicial panel and, although the corresponding exception was invoked, the court of appeal has not yet ruled on the matter;

b) the appeal is approved as a result of clerical errors;

c) while dismissing the appeal and admitting it part, the court of appeal failed to investigate the reasons for cassation invoked by the appellant;

d) the court of appeal has not ruled either one of the appeals.

The object of these appeals for annulment is the decision of the appeal court which, under the law, cannot be appealed ${ }^{5}$ given that the provisions relating to the invocation of these reasons by way of ordinary appeal or extraordinary appeal may not be applied.

This time the appeal court is responsible for this error, which either has not noticed that it was not competent to hear the appeal, or the composition of the court was not done in accordance with the law. I could have delivered a solution based on a clerical error, failed to examine an extraordinary appeal or dismissed it without ruling on the reason which would have led to another solution.

When the argument invoked is that the appellate decision was issued by an court without absolutely no jurisdiction or in violation of rules of the composition of the judicial panel, it is required to invoke the exception of jurisdictional matters or the wrong composition under the law but without the appeal court having rules on it $^{6}$. Basically, not invoking this exception also covers the cause of illegality and in equal measure the wrong resolution does not allow for a new analysis.

Only if the appeal court does not rule on the question does it become possible to use this legal remedy, so that if the exception was not invoked before the appellate court, the final decision may not be censored in the appeal for annulment. If the lack of absolute jurisdiction, beside the general one, cannot be directly invoked neither before the appellate court, nor in the first-circuit court within the conditions of the law, but directly in the appeal, compared to article 130 from the New Romanian Code of Civil Procedure, this right can no longer be exercised. So using it as a form of direct appeal will not be effective $m$ given that the admissibility requirement was not met. If this solution is not approved, the exception of no absolute, physical or territorial jurisdiction was directly invoked on appeal, and the court fails to rule on it, it would be like admitting the appeal for annulment were made only to ascertain the incapability to exercise the right to invoke this reason.

\footnotetext{
${ }^{3}$ Romanian High Court of Cassation and Justice, Commercial section, Decision no. 3655 from 14 November 2007.

${ }^{4}$ Romanian High Court of Cassation and Justice administrative and fiscal division, Decision no. 1519 from 8 March 2005 from the Revue of the Court of Cassation no. 2/2005, pp. 64-65.

${ }^{5}$ Romanian High Court of Cassation and Justice, Civil and intellectual property section, Decision no. 5180 from 26 May 2006.

${ }^{6}$ Romanian High Court of Cassation and Justice, Civil Section I, Decision no. 2930 from 2 May 2012.
} 
If the composition of the judicial panel is wrong, due to non-compliance with judicial organization rules, besides the appeal for annulment cases and alongside the violation of jurisdiction rules, all fills in the gap in the previous law when appellate decisions could not be challenged due to the lack of procedures paths, although it violated compulsory and public stipulations, which perhaps were more important than those relating to jurisdiction.

If the an appeal is made before the court and rejected, the conclusion can be appealed in a higher court, after the final judgment was delivered (article 53 paragraph 1 from the New Romanian Code of Civil Procedure), so that if the court decides on this exception, the appeal for annulment can no longer be used but rather the extraordinary appeal.

When the solution of the appellate court is the result of a clerical error ${ }^{7}$, jurisprudence has retained the fact that this stipulation must be interpreted restrictively, due to the quality of exception of the text. So it was decided that only obvious clerical errors come into this category, errors related to the formal aspects in the ruling, not just simple interpretation or assessment errors of the evidence ${ }^{8}$.

This error must have been decisive in the outcome of the appeal, so the causality between it and the solution offered by the appellate court.

If it has been claimed that by dismissing the appeal or admitting it in part the court of appeal has failed to investigate the reasons for the amendment of the cassation ${ }^{9}$, invoked ${ }^{10}$ here, there must be no fault from the party in reexamining the reasons by the court. But this omission can only be the result of the court ${ }^{11}$. Thus if the appeal has been canceled or rejected as being submitted too late, this solution is in consequence of the complaining party's attitude so therefore it is not allowed for annulment.

Similarly, if the appellate court did not resolve the appeal against the ruling, by failing to analyze it, then the applicant may submit an appeal for annulment along with the consequence of the solution of this appeal, after the annulment. In this case, the appeal for annulment is exercised to nullify the decision to appeal in its entirety because the appeals are usually related; one solution influencing another, therefore one law becomes necessary.

\section{Conclusions}

With regards to the appeal for annulment, based on jurisprudence and doctrine which have pointed out that among the hypotheses presented in article 317 from the Romanian Civil Code of Procedure from 1865 the one concerning the violation of the rules of organizing the judicial panel was missing, and the lawmaker added it, but without changing the extraordinary quality of this legal remedy through this extension.

On the contrary, the clarification made in this field, through the terms used limits the possibilities of exercising these legal remedies in regular cases, and the utility of the appeal for annulment appears as obvious in the context of reaching this irrevocable decision, or definitive as expressed in the code, which therefore can no longer be appealed and which were issued by a judicial panel constituted in violation of the law.

\section{Bibliography}

I. Deleanu, Tratat de procedură civilă, Volume II, Noul Cod de procedură civilă, "Universul Juridic" Publishing House, Bucharest, 2013;

\footnotetext{
${ }^{7}$ Romanian High Court of Cassation and Justice, Civil and intellectual property section, Decision no. 5033 from 19 June 2007.

${ }^{8}$ V.M. Ciobanu, Tratat teoretic şi practic de procedură civilă, vol. II, National Publishing House, Bucharest, 1997, pp. 423-424; Romanian High Court of Cassation and Justice, Commercial section, Decision no. 1709 from 13 May 2004, from the revue of the Court of Cassation, no. 2/2005, p. 76.

${ }^{9}$ Appellate Court of Bucharest, Section III, Decision no. 556 from 3 May 2010, Pandectele Romane, no. 10/2010, p. 218.

${ }_{10}^{10}$ Romanian High Court of Cassation and Justice, Commercial section 782 from 10 March 2009.

${ }^{11}$ Romanian High Court of Cassation and Justice, Commercial section no. 461 from 2 February 2011.
} 
V. M. Ciobanu, Tratat teoretic şi practic de procedură civilă, Volume II, National Publishing House, Bucharest, 1997;

*** New Romanian Code of Civil Procedure;

*** Romanian Civil Code of Procedure from 1865. 